\title{
KARAKTERISTIK AKUISISI DATA SENSOR INTERDIGITAL CAPACITOR UNTUK PENGUKURAN KADAR AIR PADA BATU BATA BERBASIS NON-DESTRUCTIVE TESTING
}

\author{
Isa Albanna \\ Sistem Komputer-Institut Teknologi Adhi Tama Surabaya \\ Jl. Arief Rahman Hakim No.100 Surabaya \\ Email : isaalbanna@itats.ac.id
}

\begin{abstract}
Interdigital sensor capacitor (IDC-S) is a sensor-based non-destructive testing (NDT), which is able to change the value of physical parameters into electrical quantity (capacitance). The design of the sensor $I D C-S$ in this research aim for units of measure the water content in the brick production. The general objective of this research is perform data acquisition from sensor model IDC-S in the implementation of the measurement of water content. Water is a material that has a dielectric value. Interaction of dielectric material and the electric field which is transmitted by electrode sensor coplanar IDC-S will be able to change the capacitance value. The first stage in the research is FEM numerical model simulations IDC-S using software Agros2D. The simulation results show the potential distribution around cover the electrodes. In the simulation contours there is no a potential overlap between the electrodes. Process of testing conducted by two methods: static and dynamic. In the static testing method measurement capacitance value to variation of water content. Capacitance measurement in a static method is done by standard instrumentation RCL Meter PM-6303A Fluke-Phillip. Data obtained capacitance value of about $8.2 \mathrm{pF}$ $45.5 \mathrm{pF}$ (the water content of $0 \%-70 \%$ ). The second method is the measurement of capacitance values by utilizing a square signal. The results of analysis exponential function from the measured signal outputs obtained large capacitance is $9.4 \mathrm{pF}-43.9 \mathrm{pF}$. Capacitance measurement values in the dynamic method is influenced by low frequency noise, which is identified through FFT spectrum analyzer SR 770. The research is expected that IDC-S sensor can be implemented for measurement of of water content of brick based on NDT.
\end{abstract}

Keywords : Interdigital capacitor, capacitive, Sensors, Electrodes, Dielectric Materials

\begin{abstract}
ABSTRAK
Sensor Interdigital capacitor (IDC-S) merupakan sensor berbasis non-destructive tes (NDT) yang mampu mengubah nilai parameter fisis menjadi besaran elektrik (kapasitansi). Perancangan sensor IDC-S dalam penelitian ini berfungsi sebagai unit pengukur kadar air dalam batu bata hasil produksi. Tujuan umum dari penelitian ini adalah melakukan akuisisi data dari model sensor IDC-S dalam implementasi pengukuran kadar air. Air merupakan meterial yang memiliki nilai dielektrik. Interaksi bahan dielektrik dan medan listrik yang ditransmisikan oleh elektroda coplanar sensor IDC-S akan mampu mengubah nilai kapasitansi. Tahap pertama dalam penelitian adalah simulasi numerik FEM sensor IDC-S menggunakan perangkat lunak Agros2D. Hasil simulasi menunjukkan distribusi potensial hanya berada pada sekitar elektroda. Pada kontur simulasi tidak terdapat overlap potensial antar elektroda. Proses pengujian dilakukan dengan dua metode yaitu statis dan dinamis. Pada metode pengujian statis dilakukan pengukuran nilai kapasitansi terhadap variasi kadar air. Pengukuran kapasitasni dalam metode statis dilakukan dengan instrumentasi standar RCL Meter PM 6303A Phillip-Fluke. Didapatkan data nilai kapasitansi sekitar $8.2 \mathrm{pF}-45.5 \mathrm{pF}$ (kadar air 0\% $70 \%$ ). Metode kedua adalah pengukuran nlai kapasitan dengan memanfaatkan sinyal kotak. Hasil analisa fungsi eksponensial dari sinyal luaran yang terukur didapatkan besar kapasitan adalah $9.4 \mathrm{pF}-43.9 \mathrm{pF}$. Nilai pengukuran kapasitansi pada metode dinamis dipengarui oleh beberapa derau frekuensi rendah yang teridentifikasi melaui FFT spectrume analyzer SR770. Diharapkan sensor IDC-S dapat diimplementasikan dalam pengukuran kadar air batu bata berbasis NDT.
\end{abstract}

Kata kunci : Interdigital capacitor, Kapasitan, Sensor, Elektroda, Bahan Dielektrik 


\section{PENDAHULUAN}

Batu bata merupakan material memiliki aspek nilai estetika dalam konsep tata ruang dan perancangan sipil. Penggunaan batu bata dalam sistem konstruksi hingga saat ini banyak mengalami inovasi, baik dalam rekayasa produksi bahan-campuran dan arsitektur pemasangan. Penelitian terkait batu bata dalam bidang rekayasa produksi yang telah dilakukan adalah pemanfaatan campuran limbah lumpur pengolahan air, rekayasa temperatur produksi dan campuran bahan kaolinite [1]. Selain bidang produksi, konsep pengembangan arsitektur batu bata juga dikembangkan oleh Ifada dalam penelitian yaitu eksplorasi susunan bata sebagai bidang pembentuk ruang [2]. Penggunaan bahan batu bata yang cukup besar dalam pengembangan konstruksi bangunan disebabkan oleh sifat termal yang mampu mengurangi transfer panas lingkungan terhadap suhu ruang [3] dan faktor ketersediaan material lokal yang melimpah [2]. Untuk melihat kualitas batu bata perlu dilakukan beberapa pengujian diantaranya adalah kuat tekan, densitas, karakteristik termal, penyerapan air [4]. Pengujian penyerapan air secara konvensional hanya dilakukan dengan pengukuran rasio masa basah dan kering [4]. Kelemahan metode tersebut adalah sulit ditetapkan dalam sistem produksi batu bata berbasis mesin, dimana kecepatan produksi batu bata relatif cepat dan dalam kuantitas banyak.

Pada penelitian terkait rancang bangun dan akuisisi data Sensor Interdigital Capacitor ( IDC-S) adalah rekayasa sekaligus karakterisasi data model kapasitor co-planar sebagai pendeteksi kadar air dalam material batu bata. IDC-S merupakan pengembangan sensor berbasis NonDestructive Testing (NDT) yaitu pengukuran tanpa merusak bahan uji. Pengukuran berbasis NDT dengan memanfaatkan kapasitan-dielektrik telah banyak dilakukan diantaranya adalah untuk pengukuran ketinggian level air [5], kontaminan zat berbahaya dalam makanan (pork meat) [6] dan kelembapan tanah [7]. Pengukuran NDT berbasis gelombang mikro (microwave) juga telah dilakukan untuk mengetahui tingkat kelembaban material kayu [8]. Secara umum prinsip kerja sensor IDC-S yang dikembangkan adalah nilai kapasitan berubah ketika terdapat interaksi antara medan listrik dan material uji (air). Nilai permitivitas dan cakupan dimensi kadar air yang terjebak dalam bata akan berdampak pada perubahan nilai kapasitan. Tujuan umum penelitian adalah melakukan akuisisi data dari rancangan model sensor IDC-S dalam pengukuran kadar air dalam batu bata. Diharapkan pengukuran dengan metode NDT mampu mendukung dalam pengukuran yang akurat, cepat dan mudah dalam karakterisasi sifat hasil produksi batu bata.

\section{TINJAUAN PUSTAKA}

\section{Model Sensor Interdigital Capacitor}

Sensor Interdigital capacitor (IDC-S) adalah transduser pasif dengan nilai kapasitansi dipengaruhi permitivitas bahan uji. Penemuan sensor berbasis kapasitan telah berkembang sejak tahun 70-an yang dilakukan oleh Gary D Alley dalam penelitian terkait interdigital capacitor dengan morfologi teknologi lapisan tipis untuk bidang microwave [9]. Model Interdigital capacitor adalah bentuk pengembangan dari konsep dasar kapasitor plat sejajar [5]. Pada kapasitor plat sejajar nilai kapasitan dipengaruhi oleh besar medan listrik yang melingkupi dalam cakupan dimensi dan permitivitas bahan. Model kapasitor plat sejajar memiliki besar nilai kapasitan $(\boldsymbol{C})$ yang sebanding dengan besar permitivitas bahan absolut $\left(\varepsilon_{0}\right)$ dan relatif $\left(\varepsilon_{r}\right)$. Besar nilai kapasitan dipengaruhi oleh faktor dimensi luas permukaan elektroda $(\boldsymbol{A})$ dan jarak antar plat (d), yang dibentuk dalam persamaan matematis (1).[10]

$$
C=\varepsilon_{0} \varepsilon_{r} \frac{A}{d}
$$

Besar permitivitas bahan dipengaruhi oleh parameter fisis internal bahan. Pada kapasitor plat sejajar medan listrik memiliki arah vektor dari polar positip menuju negatip (ground). Vektor tersebut melintasi bahan dielektrik yang mampu terpolarisasi. Sifat kapasitan pada kapasitor terjadi ketika proses polarisasi elektroda berinteraksi dengan bahan dielektrik. Sifat mikroskopik bahan akan membentuk pola polar sesaat setelah dialiri arus listrik. Pada sistem kapasitor plat sejajar, 
vektor medan listrik membentuk garis lurus menuju polar rendah. Pengubahan sistem plat sejajar menjadi coplanar dalam sistem kapasitor akan berdampak pada pola lintasan medan listrik yang melalui material dielektrik. Kontur vektor medan listrik membentuk belokan dengan radius bergantung jarak elektroda. Ilustrasi medan listrik pada sistem kapasitor plat sejajar dan coplanar ditunjukkan seperti pada Gambar 1, yaitu aliran medan listrik yang melingkupi suatu dielektrik [5].

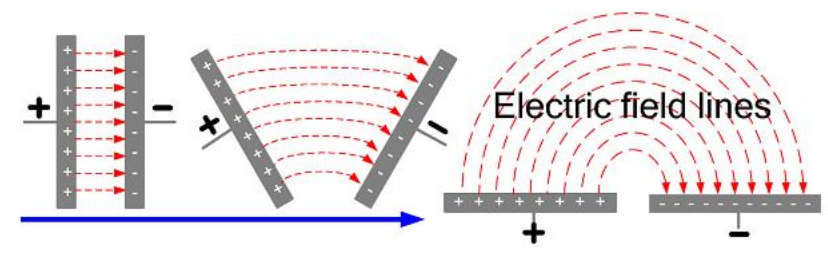

Gambar 1. Pola medan listrik pada kapasitor plat sejajar dan coplanar.[5]

Morfologi sistem IDC-S dapat dipandang sebagai bentuk kapasitor coplanar dengan perulangan kontinyu. Perulangan dengan konsistensi jarak antar elektroda untuk membuat ruang medan listrik di atas bidang elektroda. Pada Gambar 2 adalah struktur interdigital kapasitor dengan dua elektroda yaitu sumber sinyal (elektroda-A) dan penerima (elektroda-B). Pada beberapa implementasi, elektroda sumber sinyal merupakan kanal untuk memberikan sinyal masukan yang nantinya akan dipancarkan dalam material uji hingga sinyal tersebut ditangkap oleh elektroda penerima. Jenis elektroda penerima memiliki potensial lebih rendah jika dibandingkan dengan elektroda pemancar dan pada umumnya adalah berpotensial nol (ground) [11].

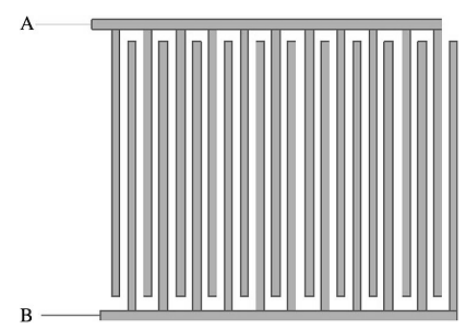

Gambar 2. Morfologi sistem interdigital capacitor (IDC-S).[11]

Nilai kapasitan pada sistem IDC-S ditentukan oleh beberapa parameter fisis, meliputi faktor geometri, permitivitas bahan penyusun dan pola sinyal listrik. Medan listrik yang memancar dari masing-masing elektroda akan membentuk struktur kapasitor di sekitar elektroda. Analisa kapasitor parsial yang terjadi ditunjukkan seperti pada Gambar 3, yaitu pembentukan kapasitor mikro per satuan pasang elektroda [10].
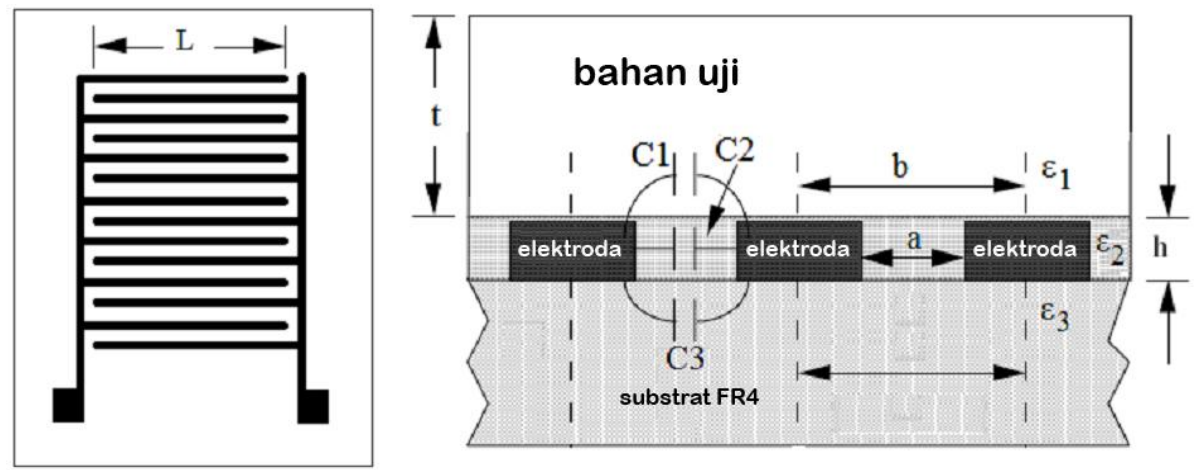

Gambar 3. Struktur mikro-kapasitor penyusun sistem IDC-S. [10]

Pada Gambar 3 terdapat struktur IDC-S dengan panjang elektroda adalah L. Pola kapasitor dalam satu pasang elektroda membentuk rangkaian kapasitor paralel. Besar nilai ekuivalensi 
kapasitan dari ketiga kapasitor $\boldsymbol{C}_{\boldsymbol{u c}}$ adalah penjumlahan dari masing-masing kapasitor $\left(\boldsymbol{C}_{\mathbf{1}}, \boldsymbol{C}_{\mathbf{2}}\right.$ dan $\boldsymbol{C}_{3}$ ). Nilai total kapasitan per-pasang elektroda dirumuskan dalam persamaan (2). Pada penjumlahan kapasitor $\boldsymbol{C}_{\boldsymbol{1}}$ dan $\boldsymbol{C}_{\mathbf{3}}$ terdapat parameter integral elliptic karena melingkupi material dengan pola setengah bola. Faktor integral elliptic diberikan dalam parameter $\boldsymbol{K}$ terhadap fungsi rasio geometri $(\mathbf{a} / \mathbf{b}) \cdot[10]$

$$
\begin{aligned}
& C=C_{u c}(N-1) \mathrm{L} \\
& C_{U C}=C_{1}+C_{2}+C_{3} \\
& C_{2}=\varepsilon_{0} \varepsilon_{2} \frac{h}{a} \\
& C_{1}+C_{3}=\varepsilon_{0}\left(\frac{\varepsilon_{1}+\varepsilon_{3}}{2}\right) \frac{K\left(\sqrt{1-\left(\frac{a}{b}\right)^{2}}\right)}{K\left(\frac{a}{b}\right)}
\end{aligned}
$$

Penyelesaian integral elliptic pada penentuan besar kapasitan IDC-S dilakukan dengan pendekatan numerik simulasi model FEM (Finite Element Method). Penyelesaian berupa pola persebaran kontur potensial (V), medan listrik (E) dan Displacement (D). Solusi dari pendekatan numerik digunakan untuk penentuan nilai besar kapasitan [11]. Pada model matematis perhitungan nilai kapasitan IDC-S dipengaruhi oleh faktor geometri dan permitivitas bahan. Perubahan permitivitas dipengaruhi oleh jenis material. Hal tersebut memungkinkan untuk dilakukan beberapa inovasi perancangan sensor dari sistem IDC-S.

\section{Sistem Akuisisi Data}

Akuisisi data merupakan metode untuk mendapatkan nilai luaran sensor hingga karakterisasi. Proses akuisisi data sensor membutuhkan sistem terintegrasi diantaranya adalah pengolah sinyal awal (pre-processing signal), penguatan, filtrasi sinyal derau (noise), digitalisasi dan pencatatan data (data logger) [5]. Perancangan pengolah awal sinyal harus melihat karakteristik dasar dari sifat sensor. Pola penentuan dilakukan dengan menganalisa dengan standar ukur instrumentasi (kalibrasi). Penanganan sensor dengan sifat Resistive-Capacitive-Inductive (RCL) dapat dilakukan dengan analisa pengukuran langsung dan pendekatan model rangkaian tanggap jaringan. Pada sifat kapasitan seperti sensor IDC-S dibutuhkan pendekatan tanggap jaringan orde satu untuk mengetahui pengotor parasitic pada rangkaian. Pada Gambar 4 merupakan rangkaian orde satu dari sistem tanggap jaringan R-C yang digunakan oleh Chetpattananondh dalam penelitian sensor level air berbasis IDC-S [5].

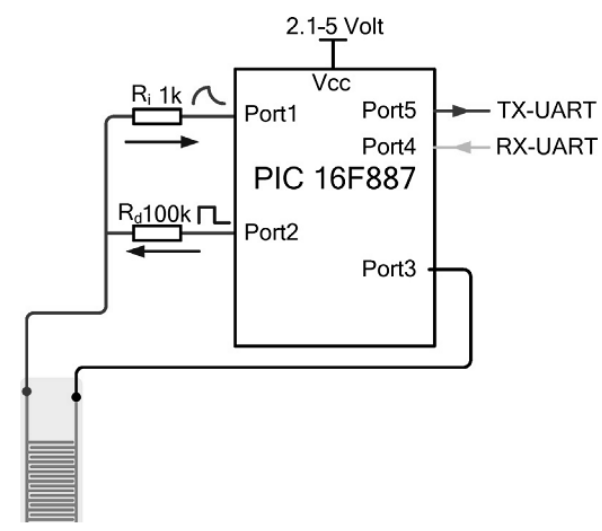

Gambar 4. Sistem akuisisi data sensor IDC-S pada pengukuran level air. [5]

Dalam rangkaian tersebut sinyal persegi yang dikeluarkan oleh mikrokontroler akan diubah menjadi sinyal gergaji oleh rangkaian R-C. Perubahan sinyal tersebut disebabkan adanya perubahan nilai pelucutan dan pengisian dalam kapasitor. Nilai luaran model matematis pada 
rangkaian tangap jaringan orde pertama dirumuskan dalam persamaan (6). Pada persamaan tersebut dilakukan transformasi invers untuk mendapatkan nilai besar kapasitan dari sensor yang telah dibentuk [5].

$$
V_{C}(t)=V_{C C} e^{-t / R_{d} C_{\text {elektroda }}}
$$

\section{METODE}

Penelitian ini dilakukan dengan empat tahap pengerjaan yaitu pengerjaan simulasi model IDC-S, tahap rancang bangun sensor IDC-S, penyusunan sistem akuisisi data dan pengujiankarakterisasi. Secara umum pada tahap perancangan model IDC-S dilakukan untuk mendapatkan pola geometri dan melihat persebaran parameter elektromagnetik. Pada tahap perancangan dan karakterisasi dilakukan perancangan perangkat keras elektronika untuk mendukung dari pengambilan data sensor IDC-S.

\section{Tahap I. Simulasi Model IDC-S}

Pada tahap ini dilakukan simulasi numerik dengan menggunakan bantuan perangkat lunak Agros2D. Agros2D adalah perangkat lunak untuk mencari solusi numerik terkait dengan FEM. Pengerjaan simulasi mengambil metode Galerkin's pada sistem elektromagnetik. Pendekatan Galerkin's bertumpu pada pembuatan tiga titik untuk membentuk segitiga dalam pencarian solusi numerik. Pada Gambar 5 adalah pengerjaan simulasi dengan Agros2D menggunakan pendekatan Galerkin's.

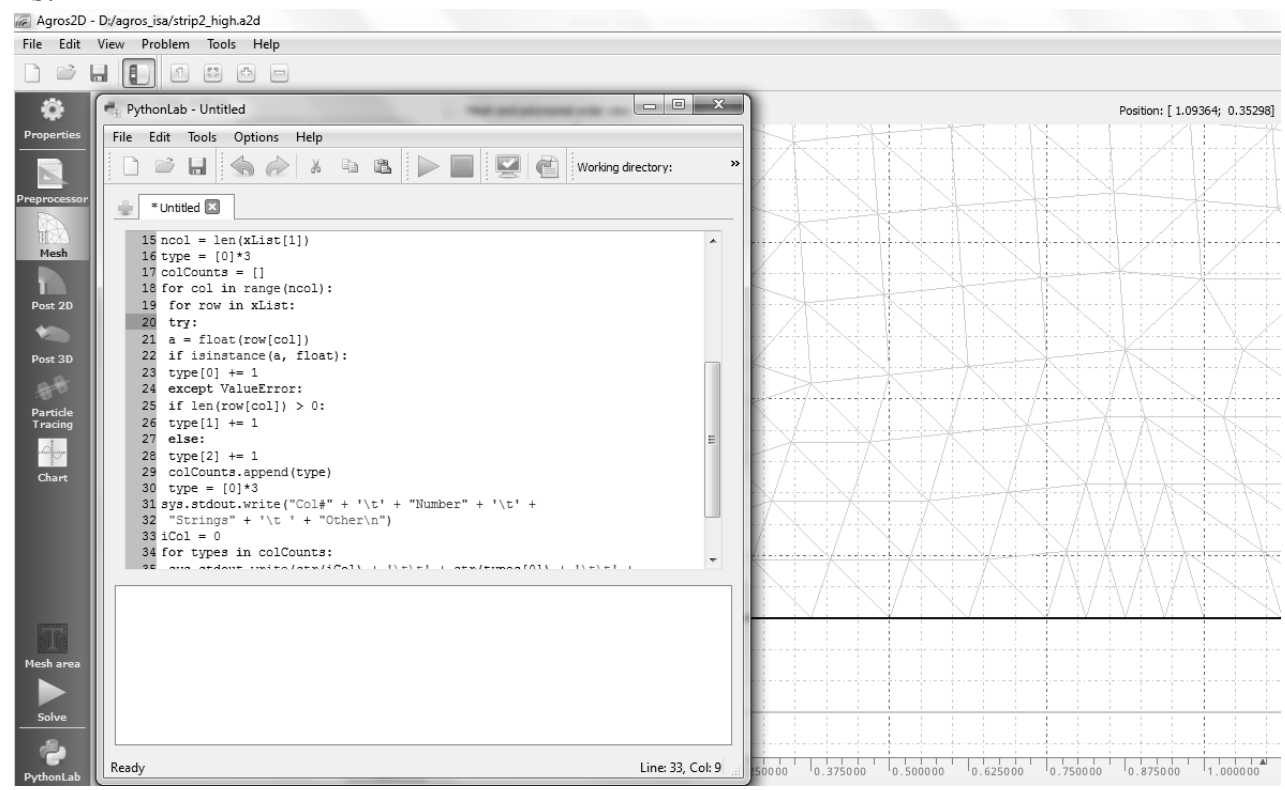

Gambar 5. Perangkat lunak Agros2D untuk solusi numerik FEM.

\section{Tahap II. Rancang Bangun Sensor IDC-S}

Pada tahap rancang bangun dilakukan perancangan sensor IDC-S menggunakan material Printed circuit Board (PCB) tipe FR4 (Flame Retardant). Jenis FR4 merupakan varian PCB dengan struktur epoxy dan nilai dielektrik adalah sekitar 4,8. Rancangan sensor ditunjukkan seperti pada Tabel 1, yaitu spesifikasi dan pola geometri sensor IDC-S. Rancangan sensor memiliki parameter panjang elektroda adalah L. Lebar geometri elektroda sumber dan penerima memiliki ukuran sama dinyatakan dalam W. Besar gap antar elektroda adalah G. 
Tabel 1. Konfigurasi sensor IDC-S dan spesifikasi geometri

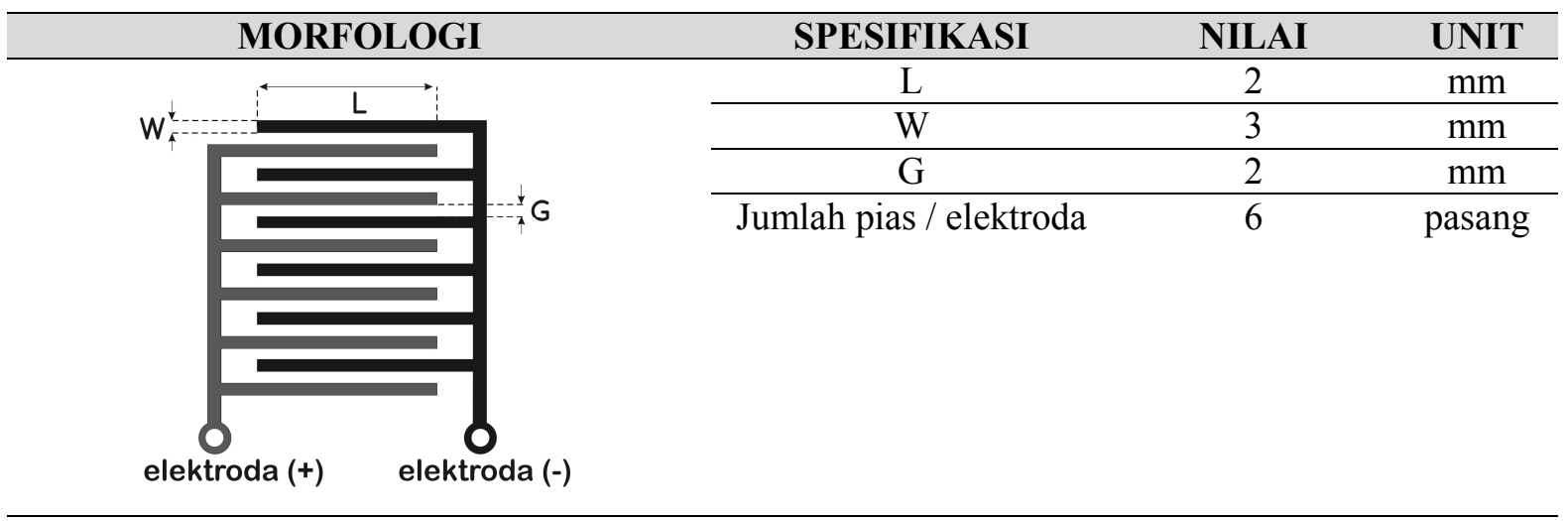

\section{Tahap III. Perancangan Sistem Akuisisi Data Sensor IDC-S}

Sistem akuisisi data sensor IDC-S terdiri dari dua blok sistem perangkat keras, yaitu sistem pengolah data rangkaian R-C orde satu dan sistem filter analog. Rangkaian R-C dalam pengolahan data digunakan sebagai pengolah data sensor bagian awal. Fungsi dari rangkaian tersebut adalah membentuk sinyal gelombang sirip. Gelombang tersebut nantinya akan ditampilkan menggunakan osiloskop digital Yokogawa DL1520.

\section{Tahap IV. Pengujian dan Karakterisasi Sensor}

Proses awal sebelum pengujian adalah persiapan bahan uji. Persiapan bahan uji digunakan batu bata dengan dimensi adalah $2 \times 2 \times 3 \mathrm{~cm}^{3}$. Batu bata tersebut dikeringkan dalam pemanas listrik dengan suhu $100 \mathrm{C}$ dalam waktu 15 menit untuk mengurangi kadar air yang terjebak dalam porositas batu tersebut. Untuk membuat variasi kadar air dalam batu bata dilakukan perendaman batu bata dengan variasi volume air. Bata yang bersifat porus akan menyerap air yang diletakkan dalam sebuah wadah. Besar kadar air pada batu bata dinyatakan dalam prosentase (\%). Penentuan prosentase dilakukan dengan pengurangan massa basah dan kering kemudian dibandingkan dengan massa kering. Perhitungan prosentase kadar air dalam batu bata dirumuskan dalam persamaan (7). Proses berikutnya adalah pengujian sensor IDC-S.

$$
\text { kadar air }(\%)=\frac{\left(m_{\text {basah }}-m_{\text {kering }}\right)}{m_{\text {kering }}} 100 \%
$$

Proses pengujian dilakukan dua metode, yaitu metode statis dan dinamis. Pengujian statis dilakukan dengan cara melihat perubahan nilai kapasitansi ketika diberikan perlakuan pada sensor IDC-S. Pengujian dinamis dilakukan dengan melakukan pengujian dengan respon tanggap jaringan gelombang kotak. Proses pengujian ditunjukkan dalam Gambar 6, yaitu skema pengujian dan luaran hasil. Pada proses pengujian sistem sensor IDC-S dibutuhkan beberapa instrumentasi ukur standar diantaranya adalah :

1. Osiloskop digital Yokogawa DL1520

2. RCL Meters PM 6303A Phillip-Fluke

3. FFT Spectrum Analyzers SR770 Stanford Research Systems

Instrumentasi osiloskop digunakan untuk melihat pola gelombang dan lebar waktu periode gelombang. Pengambilan data periode pada pengolahan data digunakan untuk proses penentuan nilai besar kapasitan dengan bantuan persamaan (6). Untuk melihat apakah gelombang yang masuk pada rangkaian terbebas dari gelombang derau, maka dilakukan pengukuran frekuensi luaran dari sensor menggunakan Fast Fourier Transform (FFT) spektrum analyzer SR770. Spektrum analyzer FFT berfungsi sebagai transformasi gelombang dari domain waktu menjadi domain frekuensi. Hasil pengukuran FFT spektrum analyzer didapatkan informasi beberapa puncak (peak) frekuensi yang membaur dalam satu spektrum gelombang (time domain). Pengukuran nilai besar kapasitan 
sensor IDC-S dengan metode statis dilakukan dengan instrumentasi RCL Meters PM 6303A Phillip-Fluke. RCL meter akan mengeluarkan data besar kapasitan sensor IDC-S secara langsung.

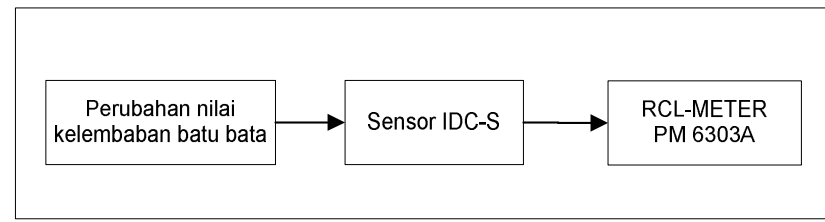

(a)

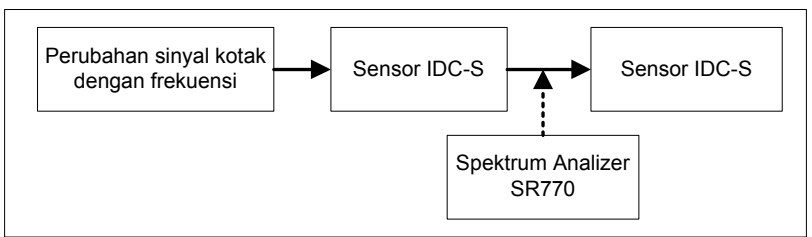

(b)

Gambar 6. a) pengujian statis sensor IDC-S, b) pengujian tangap jaringan sistem dinamis.

\section{HASIL DAN PEMBAHASAN}

\section{Pemodelan Finite Element Method IDC-S}

Hasil model IDC-S menggunakan perangkat lunak Agros2D berbasis pemrograman Python di dapatkan pola kontur distribusi potensial seperti pada Gambar 7. Distribusi potensial positip dan ground membentuk pola setengah lingkaran. Bentuk setengah lingkaran mengikuti dari model elliptic kontur kapasitor coplanar. Pola potensial melingkupi material uji yang menyebabkan adanya interaksi medan listrik dan material dielektrik. Pada perancangan model menggunakan Agros2D, pengambilan distribusi potensial hanya kontur koordinat tegak lurus dengan bidang elektroda. Pada simulasi model tidak diberikan material uji dan permukaan elektroda langsung bersentuhan dengan udara (dielektrik $\approx 1$ ). Pada simulasi dengan media udara transmisi potensial listrik mampu melingkupi hingga satuan jarak tertentu.

Model dikembangkan dengan besar potensial pada elektroda adalah 5volt. Untuk batas (boundary) model digunakan pendekatan medan Newman dengan rapat potensial permukaan adalah nol. Pemilihan batas dengan pendekatan medan Newman berfungsi untuk menjaga agar batas model tidak mengganggu potensial elektroda. Pengujian dengan besar potensial standar tegangan digital yaitu 5 volt pada masing-masing elektroda menunjukkan model persebaran potensial yang ter-lokal di sekitar elektroda. Dari model yang dihasilkan, tidak terlihat adanya penumpukan kontur potensial yang terjadi antar elektroda. Potensial hanya tersebar pada cakupan dimensi elektroda dan tidak saling mempengaruhi dari pasangan elektroda lainnya. Pemilihan tegangan uji 5 volt bertujuan untuk penyesuaian pada bidang implementasi yaitu tegangan standar instrumentasi digital.

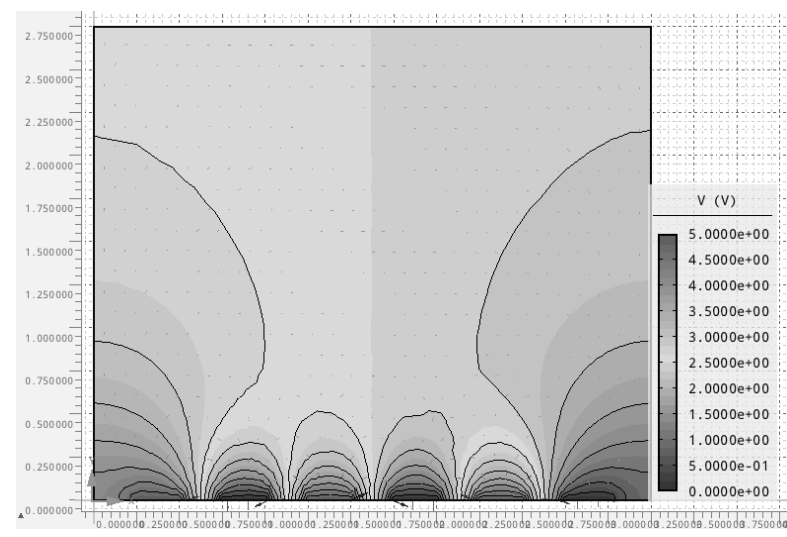

Gambar 7. Pola kontur distribusi potensial pada sensor IDC-S 


\section{Karakterisasi Statis Nilai Kapasitan Sensor IDC-S}

Metode pengukuran karakterisasi statis nilai kapasitansi sensor IDC-S dilakukan dengan mengukur secara langsung besar kapasitansi dengan menggunakan instrumentasi RCL-Meter. Pengukuran langsung melalui RCL meter ditunjukkan seperti pada Gambar 8, dalam pengukuran menggunakan RCL meter terlihat dominasi terdapat pada sistem kapasitor.
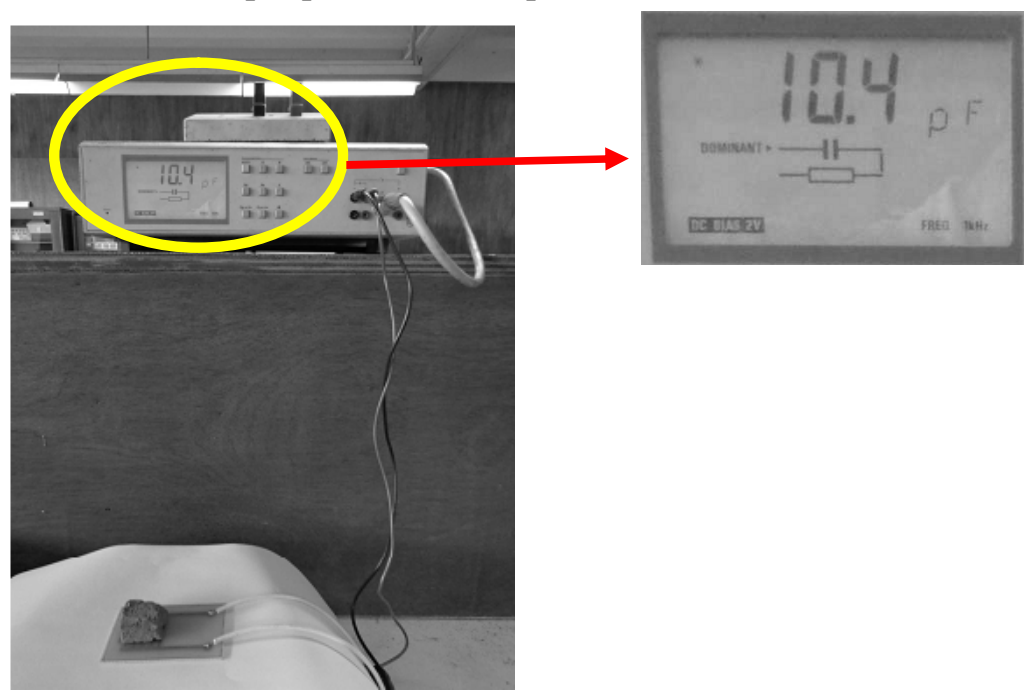

Gambar 8. Pengukuran kapasitansi IDCS dalam pengindraan kadar air batu bata menggunakan instrumentasi standar LCR-meter.

Pengukuran metode statis dilakukan untuk melihat pengaruh nilai kapasitan terhadap kadar air pada batu bata. Pengukuran dilakukan dengan variasi penetrasi kadar air dalam batu bata dari 0 $\%$ sampai dengan $70 \%$. Parameter kadar air dengan besar nilai $0 \%$ artinya batu bata dalam kondisi kering. Dari hasil pengujian statis didapatkan hasil seperti pada Gambar 9, yaitu grafik hubungan nilai kapasitansi terhadap kadar air yang terperangkap dalam batu bata. Pada grafik tersebut terlihat kurva yang cenderung berpola linier. Perubahan nilai kapasitansi disebabkan adanya kuantitas dielektrik pada air yang mengisi ruang porus dalam batu bata. Kuantitas yang cukup besar memberikan dampak kenaikan nilai kapasitansi. Variasi perlakuan perubahan kadar air dalam batu bata hanya bisa dilakukan secara optimal pada nilai $70 \%$. Hal tersebut disebabkan karakteristik dari batu bata yang sudah melawati batas maksimum penyerapan air. Keadaan jenuh terjadi ketika hampir seluruh porositas batu bata pada lapisan permukaan terisi oleh air. Tingkat jenuh penyerapan batu bata dipengaruhi oleh kualitas batu bata. Pada pengujian sample hanya mampu menyerap air hingga $70 \%$ dari massa kering batu bata.

Pada grafik pengujian teridentifikasi pola model linier dengan yang merujuk pada korelasi nilai kapasitansi dan kadar air yang terkandung dalam batu bata. Proses penarikan model ditujukan untuk melihat konversi nilai dari besaran fisis (kadar air) menjadi nilai besaran kelistrikan (kapasitansi dan tegangan listrik). Model matematis kurva fitting ditunjukkan seperti pada persamaan (8), yaitu persamaan linier konversi nilai luaran sensor IDCS dan pengukuran nilai kadar air. Nilai $\mathrm{y}(\mathrm{x})$ adalah besar kapasitansi yang terukur dengan fungsi terhadap nilai $\mathrm{x}$ sebagai kadar air.

$$
y(x)=0.53 x+5.26
$$




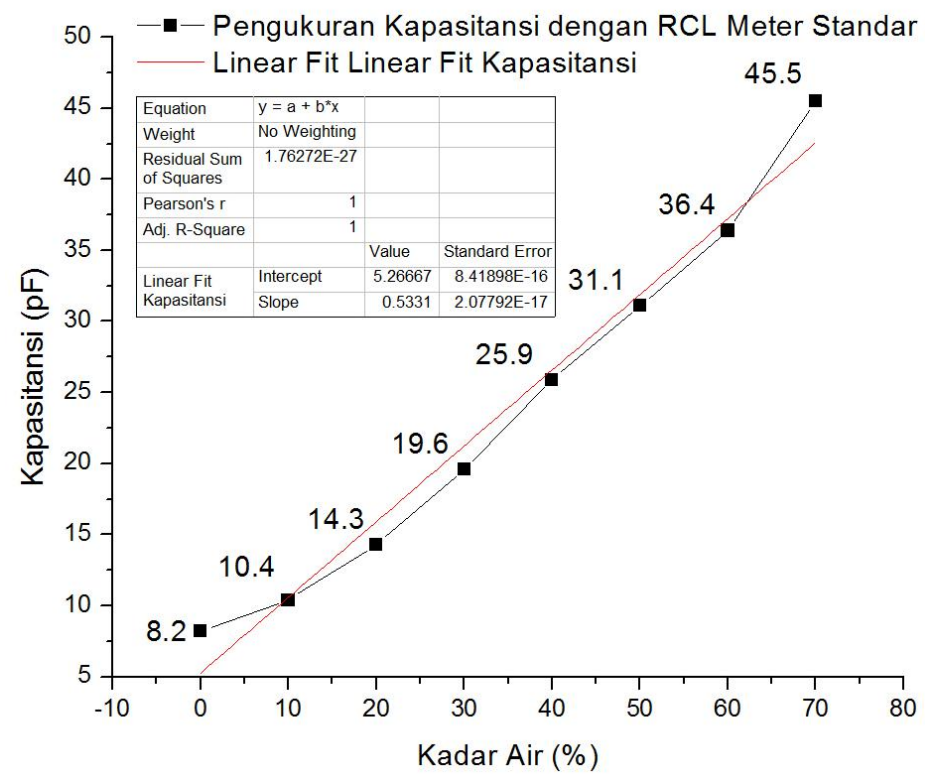

Gambar 9. Grafik hubungan nilai kapasitansi dan kadar air pada pengujian sensor IDC-S.

\section{Karakterisasi Tangap Dinamis Sensor IDC-S}

Pengujian tangap dinamis dilakukan dengan melihat respon sensor IDC-S ketika dilakukan pemberian sinyal kotak. Model ekuivalensi dari sistem pengujian tangap dinamis adalah kombinasi rangkaian R-C. Pengujian tangap dinamis sensor bertujuan untuk melihat karakteristik sensor jika dilakukan integrasi dengan instrumentasi elektronika lain yang berada dalam sebuah sistem pengukuran fisis. Hasil pengukuran ditunjukkan dengan luaran sinyal sirip gergaji dengan pola periode tertentu. Pada Gambar 10.a adalah sinyal masukan yang dihubungkan dengan sistem sensor IDC-S. Hasil luaran sinyal ditunjukkan seperti pada Gambar 10.b, yaitu tampilan sinyal sirip (gergaji) dengan periode. Hasil luaran sinyal sirip merupakan luaran yang terukur setelah dilakukan pemfilteran analog (filter tapis rendah).

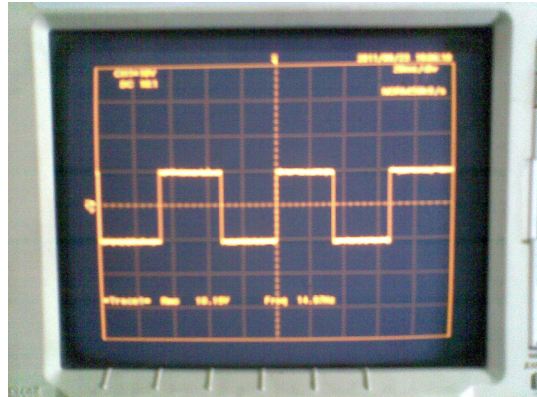

(a)

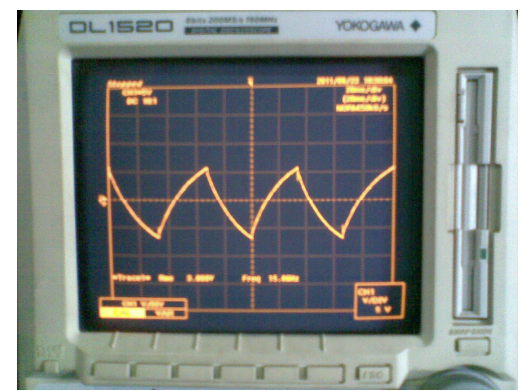

(b)

Gambar 10. a) pola sinyal masukan berupa gelombang kotak; b) hasil luaran sinyal dari model sensor IDC-S

Pada sinyal sirip merupakan bentuk eksponensial peluruhan dan pengisian kapasitor ketika dilewatkan sinyal persegi. Pengolahan sinyal sirip dilakukan dengan analisa fungsi eksponensial. Proses invers eksponensial dari persamaan (6) digunakan untuk menentukan besar kapasitan dari sistem sensor ketika dilakukan pengujian tangap dinamis. Langkah proses inversi eksponensial dilakukan dengan melihat rasio puncak (peak) tegangan masuk (Vo) dan tegangan luaran sinyal sirip $(\boldsymbol{V})$. Hasil invers rasio tegangan, pengukuran periode $(\boldsymbol{t})$ dan transformasi logaritma natural digunakan untuk penentuan nilai kapasitansi. Hasil perhitungan nilai kapasitansi ditunjukkan dalam Tabel 2, yaitu tabel pengambilan data nilai kapasitansi menggunakan metode statis dan dinamis. 
Dari hasil pengujian terlihat adanya perbedaan antara pengukuran statis dan dinamis. Perbedaan yang terjadi dapat disebabkan karena faktor sinyal listrik bercampur dengan derau (noise). Adanya derau dapat diidentifikasi dengan pengukuran FFT sinyal yang masuk pada sensor. Hasil pengambilan data FFT ditunjukkan pada Gambar 11. Pada spektrum analyzer terlihat adanya peak hanya pada satu frekuensi, akan tetapi masih terdapat derau pada beberapa frekuensi dan menempati pita energi rendah. Keberadaan derau elektronik mempengaruhi dari sifat transien sinyal dan berakibat pada pergeseran periode. Pada penelitian validasi dilakukan mengacu pada metode statis, karena pada metode dinamis terdapat derau dengan densitas frekuensi rendah. Dari hasil pengukuran menggunakan FFT analyzer sinyal derau elektronik dapat dilakukan reduksi dengan cara pemfilteran orde tinggi dan filter digital dengan algoritma pemrograman.

Tabel 2. Komparasi hasil perhitungan kapasitansi dengan metode statis dan dinamis.

\begin{tabular}{cccc}
\hline \multirow{2}{*}{ No } & \multirow{2}{*}{ Besar Kadar air (\%) } & \multicolumn{2}{c}{ Besar nilai kapasitan } \\
\cline { 2 - 4 } & 0 & 8.2 & Metode statis \\
\hline 1 & 10 & 10.4 & 9.4 \\
\hline 2 & 20 & 14.3 & 13.5 \\
\hline 3 & 30 & 19.6 & 21.2 \\
\hline 4 & 40 & 25.9 & 26.1 \\
\hline 5 & 50 & 31.1 & 29.5 \\
\hline 6 & 60 & 36.4 & 35.8 \\
\hline 7 & 70 & 45.5 & 43.9 \\
\hline 8 & & &
\end{tabular}

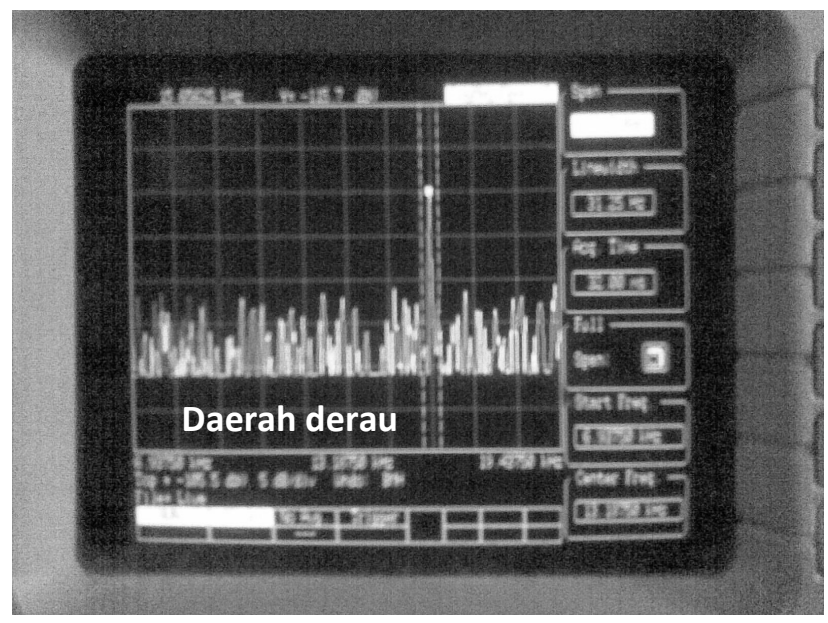

Gambar 11. FFT Spektrum analyzer dalam proses pemantauan derau (noise).

Proses kalibrasi sensor IDCS dengan standar instrumentasi LCR-meter ditunjukkan dalam Gambar 12, yaitu grafik komparasi nilai pengukuran kapasitan menggunakan RCL-meter dan sensor IDCS. Dalam grafik tersebut terdapat nilai selisih pengukuran antara alat standar dengan sistem sensor IDCS yang telah dirancang. Rasio perbedaan nilai terhadap perubahan nilai kapasitan ketika dilakukan perubahan perlakuan bahan uji ditunjukkan pada Tabel 3. Hasil rasio pergeseran absolut nilai pembacaan kapasitansi tidak lebih hanya berada dalam kisaran $0,2 \mathrm{pF}$ sampai dengan $1,6 \mathrm{pF}$. 
Tabel 3. Selisih absolut pergeseran nilai kapasitansi sistem IDCS.

\begin{tabular}{ccccc}
\multirow{2}{*}{ No } & \multirow{2}{*}{ Kadar Air } & \multicolumn{2}{c}{ Pembacaan nilai kapasitansi } & \multirow{2}{*}{$\begin{array}{c}\text { Selisih } \\
\text { Absolut }\end{array}$} \\
\cline { 2 - 4 } & 0 & RCL Meter & Sistem IDCS & \\
\hline 1 & 10 & 8.2 & 9.4 & 1.2 \\
\hline 2 & 20 & 10.4 & 11.5 & 1.1 \\
\hline 3 & 30 & 14.3 & 13.8 & 0.5 \\
\hline 4 & 40 & 19.6 & 21.2 & 1.6 \\
\hline 5 & 50 & 25.9 & 26.1 & 0.2 \\
\hline 6 & 60 & 31.1 & 29.5 & 1.6 \\
\hline 7 & 70 & 36.4 & 35.8 & 0.6 \\
\hline 8 & & 45.5 & 43.9 & 1.6 \\
\hline
\end{tabular}

\section{KESIMPULAN}

Kesimpulan yang diambil dari penelitian terkait akuisisi data sensor IDC-S untuk pengukuran kadar air dalam batu bata adalah :

1. Pada tegangan 5 volt distribusi potensial tidak terjadi interferensi antar elektroda dalam IDC-S

2. Nilai kapasitan sensor IDC-S dengan referensi batu bata kering adalah sekitar $8.2 \mathrm{pF}$

3. Terdapat derau elektronik ketika dilakukan intergrasi sensor IDC-S dengan sistem tangap jaringan dan hasil pengukuran kapasitansi adalah sekitar $9.4 \mathrm{pF}$ yang terukur pada batu bata kering.

4. Hasil selisih absolut antara pengukuran IDCS menggunakan instrumentasi standar dan sistem adalah sekitar $0,2-1,6 \mathrm{pF}$.

\section{UCAPAN TERIMA KASIH}

a. Yayasan Pendidikan Teknik Surabaya (YPTS) atas pendanaan penelitian internal mandiri institusi.

b. Laboratorium Fisika Bangunan dan Instrumentasi Elektronika, Jurusan Fisika-MIPA ITS.

c. Laboratorium Sistem Komputer ITATS

\section{DAFTAR PUSTAKA}

[1] Huda, M. and E. Hastuti, 2012. Pengaruh Temperatur Pembakaran dan Penambahan Abu Terhadap Kualitas Batu Bata, JURNAL NEUTRINO, vol. 0,

[2] Nisa, I. J., T. Mustikawati, and B. S. Yatnawijaya, 2014. Ekplorasi Susunan Bata sebagai Bidang Pembentuk Ruang, Jurnal Mahasiswa Jurusan Arsitektur, vol. 2,

[3] Santosa, M. and V. T. Noerwasito, 2007. Pengaruh "Thermal Properties" Material Bata Merah Dan Batako sebagai Dinding, Terhadap Efisien Enerji dalam Ruang Di Surabaya, DIMENSI (Journal of Architecture and Built Environment), vol. 34, pp. pp.-147-153.

[4] Mizwar, A. and S. R. Amalia,2012. Pemanfaatan Limbah Lumpur Pengolahan Air Sebagai Bahan Pembuatan Batu Bata, Bumi Lestari, vol. 12,

[5] Chetpattananondh, K., T. Tapoanoi, P. Phukpattaranont, and N. Jindapetch, 2014. A selfcalibration water level measurement using an interdigital capacitive sensor, Sensors and Actuators A: Physical, vol. 209, pp. 175-182.

[6] Mukhopadhyay, S. C. and C. P. Gooneratne, Comparison of Electromagnetic Response of Planar Interdigital Sensors: Quality Testing Of Pork Meat, in Electronic Design, Test and Applications, 2006. DELTA 2006. Third IEEE International Workshop on, 2006, p. 6 pp. 
[7] Mizuguchi, J., J. C. Piai, J. A. D. Franca, M. B. D. M. Franca, K. Yamashita, and L. C. Mathias, 2015. Fringing Field Capacitive Sensor for Measuring Soil Water Content: Design, Manufacture, and Testing, IEEE Transactions on Instrumentation and Measurement, vol. 64, pp. 212-220.

[8] Vallejos, C. and W. G, Grote, Wood moisture content measurement at $2.45 \mathrm{GHz}$, in Microwave and Optoelectronics Conference (IMOC), 2009 SBMO/IEEE MTT-S International, 2009, pp. 221-225.

[9] Alley, G. D., 1970. Interdigital Capacitors and Their Application to Lumped-Element Microwave Integrated Circuits, IEEE Transactions on Microwave Theory and Techniques, vol. 18, pp. 1028-1033.

[10] Angkawisittpan, N. and T. Manasri, 2012. Determination of Sugar Content in Sugar Solutions using Interdigital Capacitor Sensor, Measurement Science Review, vol. 12, pp. 8-13.

[11] Dean, R. N., A. K. Rane, M. E. Baginski, J. Richard, Z. Hartzog, and D. J. Elton,2012. A Capacitive Fringing Field Sensor Design for Moisture Measurement Based on Printed Circuit Board Technology, IEEE Transactions on Instrumentation and Measurement, vol. 61, pp. 1105-1112. 